\title{
Presença de resíduos de antibióticos no leite cru refrigerado de propriedades leiteiras da região sul do Espírito Santo
}

Romulo Dutra Uliana', Sayanne Luns Hatum de Almeida, Dirlei Molinari Donateli, Graziela Barioni, Renata Cogo Clipes, Marcus Vinícius Gonçalves Viana, Mayra Cardozo Mendes, Isabella Vilhena Freire Martins, Samuel Pereira Botelho, Layara Pestana Sarmento

Centro de Ciências Agrárias e Engenharias, Universidade Federal do Espírito Santo (UFES), Vitória, ES, Brasil

*Autor correspondente

e-mail: romulo_uliana@hotmail.com

\section{Resumo}

A ocorrência de resíduos de antibióticos no leite é um sério problema que afeta a saúde pública e que durante anos tem sido preocupação constante para as autoridades sanitárias devido aos efeitos tóxicos destes compostos. Podendo causar alergias e até mesmo alguns tipos de câncer, existe também a possibilidade de favorecer o desenvolvimento de microrganismos patogênicos e resistentes, além de alterar toda a microbiota do trato gastrintestinal. 0 presente trabalho tem como objetivo detectar possíveis resíduos de antibióticos da classe dos beta-lactâmicos e das tetraciclinas no leite cru refrigerado de tanques de expansão e armazenamento de propriedades leiteiras da região sul do estado do Espírito Santo. Foram selecionadas 30 propriedades destinadas à produção de leite, em oito municípios diferentes da região sul do estado do Espírito Santo (Alegre, Bom Jesus do Norte, Ibatiba, Ibitirama, Irupi, Jerônimo Monteiro, Muniz Freire e São Jose do Calçado), por meio de cadastro no Instituto de Defesa Agropecuária e Florestal do Espírito Santo (IDAF). Um termo de consentimento e livre esclarecimento do projeto foi apresentado aos responsáveis pelas propriedades, e somente após a assinatura do termo a propriedade fez parte do projeto. Foram aplicados a todos os responsáveis uma entrevista estruturada, abordando as variáveis relativas aos dados da propriedade, produção de leite, controle e sanidade dos animais. Amostras de leite do tanque de expansão e/ou dos galões individuais de cada propriedade foram coletadas em tubos Falcons estéreis, identificadas, acondicionadas e transportadas em caixa isotérmica com gelo para o Laboratório de Inspeção de Produtos de Origem Animal do Hospital Veterinário da Universidade Federal do Espírito Santo, onde foram realizadas as análises de resíduos de beta-lactâmicos e tetraciclinas no leite cru refrigerado através do teste Eco Teste $\mathrm{BT}^{\circledR}$, seguindo as recomendações do fabricante. Das 30 propriedades avaliadas, quatro (13,33\%) apresentaram resíduos de antibióticos beta-lactâmicos: duas em São José do Calçado, uma em Ibitirama e uma em Jerônimo Monteiro. Não existiram resultados positivos para a classe das tetraciclinas nas amostras das propriedades analisadas ou não continham quantidade maior 
que o limite máximo de resíduo (LMR) permitido no leite. A presença de inibidores bacterianos encontrados nas amostras analisadas, contrariando a legislação em vigor, revela a necessidade de atuação mais rigorosa dos órgãos de Saúde Pública, quer seja através da inspeção, quer seja através de programas educativos junto à população envolvida na cadeia de produção, já que os resultados obtidos são considerados elevados e causam preocupação por parte das empresas beneficiadoras e, principalmente, do consumidor final.

Apoio Financeiro: Fundação de Amparo à Pesquisa e Inovação do Espírito Santo (FAPES). 